\title{
Tracking Salmonellae in Australia
}

D. Lightfoot, T. Sieh, J. Powling

\begin{abstract}
Abstrak
Usaha pencegahan yang efektif terhadap penyakit yang ditularkan melalui makanan memerlukan suatu sistem surveilans yang menyeluruh dan akurat. Unit Diagnostik Mikrobiologi telah mengembangkan dan menjalankan suatu Skema Surveilans Patogen Enterik Nasional (NEPSS). Informasi tentang patogen enterik terutama Salmonella dari kasus-kasus dari sumber manusia dan bukan manusia masuk ke NEPSS dari berbagai laboratorium yang ada di Australia. Setiap tahun diperoleh 6.000 masukan dari kasus manusia dan sumber bukan manusia. NEPSS telah berjalan selama 15 tahun dan telah menerima 180.000 masukan. Secara garis besar masukan yang diterima dapat dikategorikan sebagai dari sumber manusia, binatang, susu \& produk susu, telur \& produk telur, lingkungan dan air, dan makanan untuk manusia dan binatang. Setiap kategori ini kemudian dirinci lebih spesifik. Kasus Salmonella berbeda untuk setiap negara bagian, dari sejumlah 18,4/100.000 untuk Victoria hingga 238,3/100.000 untuk Northern Territory (data 1996). Meskipun terdapat variasi dari masing-masing serovar pada setiap negara bagian, S.typhimurium masih merupakan serovar yang dominan. Pada waktu ini S. enteritidis tipe faga 4 tidak lagi merupakan penyebab utama keracunan makanan di Australia yang diperoleh dari luar terutama dari Asia Tenggara. NEPSS juga mendapat informasi lain yang merupakan petanda penting untuk penelitian epidemiologis, seperti pola resistensi antibiotika, jenis faga, variasi biokimiawi, dan sidik jari molekuler. Suatu sistem pemberitahuan dini untuk mendeteksi kemungkinan terjadinya suatu kejadian luar biasa dengan menggunakan data NEPSS, dilaksanakan setiap minggu.
\end{abstract}

\begin{abstract}
For effective food-borne disease prevention a country requires a comprehensive and accurate surveillance scheme. The Microbiological Diagnostic Unit developed and operates the National Enteric Pathogen Surveillance Scheme (NEPSS). Information about enteric pathogens, particuarly Salmonella from human cases and non human sources, is submitted to the NEPSS from laboratories Australiawide. Each year approximately 6,000 notifications from both human cases and non human sources, are received. The NEPSS has operated for over 15 years with over 180,000 notifications. The broad categories for notification are human, animal, milk products, egg and egg products, environment and water, and animal and human foodstuffs. Within each category more specific information is requested. The Salmonella case rate varies considerably between each state with a range of 18.4/100,000 for Victoria and 238.3/100,000 for the Northern Territory (1996 data). While there are specific differences in the dominant Salmonella serovars in each state, S.typhimurium remains the main seronvar. To date $\mathrm{S}$. enteritidis phage type 4 is not a major cause of Australian acquired overseas, particularly from Southeast Asia. The NEPSS retains other information, such as antibiotic resistance profiles, phage types, biochemical variation, molecular finger printing all of which are crucial markers in epidemiological investigations. An early warning system to detect potential outbreaks utilising the NEPSS data base, is operated each week.
\end{abstract}

Microbiological Diagnostic Unit, The University of Melbourne, Parkville, Victoria, Australia, 3052 